\title{
PENERAPAN METODE INTERAKTIF DALAM PERMAINAN KARTU JACK DAN JACKY UNTUK MENINGKATKAN KOSAKATA SISWA KELAS X SMK NEGERI 7 MAKASSAR
}

\section{IMPLEMENTATION OF INTERACTIVE METHOD THROUGH JACK AND JACKY CARD TO IMPROVE VOCABULARY OF STUDENTS CLASS X AT SMK NEGERI 7 MAKASSAR}

\author{
Agussari Henny \\ SMK Negeri 7 Makassar \\ agussarihenny2020@gmail.com
}

\begin{abstract}
The aims of this research are to know implementation of interactive method through Jack and Jacky Card in improving students' vocabulary ability (Irregular verbs) of simple past tense topic and to know whether there is any change of behavioral and attitude of X PS 2 students at SMK Negeri 7 Makassar. Research methods was class action research design. It was conducted into two cycles in each cycles consists of planning, action, observation and reflection. In collecting data the researcher gave evaluation at the end of learning as compared between the scores of pretest and post test. While interviews, observation, questionnaire, document and journal as non test. The results showed that the students' vocabulary ability could improve in Irregular verbs as a simple past tense subject by using Jack and Jacky cards. Similarly, the change in behavior is to show positive change.
\end{abstract}

Keywords: attitude, behavioral, Jack and Jacky card, students' vocabulary ability.

\begin{abstract}
Abstrak
Penelitian ini bertujuan untuk mengetahui penerapan metode interaktif melalui permainan kartu Jack dan Jacky dalam meningkatkan kemampuan kosakata pada kata kerja (Irregular verbs) pokok bahasan Simple Past Tense dan untuk mengetahui perubahan perilaku dan sikap pada siswa kelas X PS 2 SMK Neg 7 Makassar. Penulis menggunakan desain penelitian tindakan kelas yang dilakukan dalam dua siklus, tiap siklus terdiri dari dua kali pertemuan yang terdiri dari perencanaan, tindakan, pengamatan dan refleksi. Pengambilan data dengan memberikan evaluasi sebagai bahan penilaian hasil kerja siswa pada pretes dan postes. Data non tes di ambil dari pengamatan, angket, dokumen serta jurnal pembelajaran. Hasil penelitian menunjukkan bahwa kemampuan kosakata siswa dapat meningkat pada kata kerja tidak beraturan pokok bahasan simple past tense dengan menggunakan kartu Jack and Jacky. Begitu pula pada perilaku dan sikap menunjukkan perubahan yang positif.
\end{abstract}

Kata Kunci: kartu Jack and Jacky, kemampuan kosakata, perilaku, sikap.

\section{PENDAHULUAN}

Kemampuan Bahasa Inggris (English language skill) merupakan sebuah syarat mutlak yang harus dimiliki di era komunikasi dan globalisasi saat ini. Oleh karena pembelajaran bahasa Inggris (English language learning) di jenjang Sekolah Menengah Kejuruan (SMK) merupakan mata pelajaran yang wajib diajarkan dengan harapan setelah siswa menamatkan studinya di SMK, mereka mampu membekali diri menjadi individu yang cerdas, terampil dan berkepribadian sebagai bekal hidup di masa mendatang dalam mencari peluang pekerjaan (job seeker).

Penguasaan materi pelajaran bahasa Inggris dalam jenjang SMK meliputi empat keterampilan berbahasa, yaitu: menyimak, berbicara, membaca dan menulis. Semua itu didukung oleh unsur-unsur bahasa yang tidak kalah pentingnya yaitu: kemampuan kosa kata (vocabulary), tata bahasa (grammar) dan pengucapan (pronounciation) Penguasaan bahasa memerlukan bekal kosakata yang 
banyak dan bentuk tata bahasa yang memadai. Kosakata yang banyak tanpa didasari dengan tata bahasa yang kuat maka mustahil kita bisa memahami dengan baik dari salah satu keterampilan bahasa Inggris di atas demikian sebaliknya, tata bahasa yang baik tanpa memiliki kosakata yang banyak maka suatu tulisan tidak dapat di baca dengan sempurna [1]. Penguasaan kosakata berpengaruh dalam pembuatan kalimat dan pemahaman bahasa Inggris.

Penguasaan kosakata merupakan ukuran pemahaman seseorang terhadap kosakata suatu bahasa dan kemampuannya menggunakan kosakata tersebut baik secara lisan maupun tertulis [2]. Penguasaan kosakata adalah kemampuan seseorang untuk mengenal, memahami, dan menggunakan kata-kata dengan baik dan benar dengan mendengar, berbicara, membaca dan menulis [3]. Ref. [4] menyatakan "How important is vocabulary? Without grammar very little can be conveyed, without vocabulary nothing can be conveyed". "Seberapa pentingkah kosa kata? Tanpa pengetahuan tentang tata bahasa sangat sedikit sekali yang bisa disampaikan, tanpa kosa kata tidak ada yang bisa disampaikan".

Kesulitan siswa kelas X PS 2 (Pekerja Sosial) dalam pembelajaran Bahasa Inggris yaitu tidak mengetahui kata kerja tidak beraturan (irregular verbs) pada kompetensi dasar penggunaan simple past tense. Hal ini di rasakan oleh penulis siswa hanya menghafal atau melihat kamus, terkadang guru bertanya kepada siswa tentang apa arti kosa kata pada soal bacaan yang di berikan, hanya beberapa siswa saja yang mampu menjawab dengan tepat sebagian besar mereka hanya diam sehingga membutuhkan waktu lama dalam pembelajaran bahasa Inggris. Kendala lainnnya yang di rasakan guru adalah perilaku siswa yang tidak mendukung seperti, kurang perhatian, kurang motivasi, malas membuka kamus untuk mengetahui arti kata khususnya pada penguasaan pada kata kerja irregular verbs.

Rendahnya hasil belajar siswa dalam memahami kata kerja irregular verbs dalam memahami penggunaan simple past tense juga terlihat pada hasil ulangan harian, dimana siswa masih bingung dan tidak bisa mengubah kata kerja tidak beraturan (irregular verbs) pada materi simple past tense, sehingga siswa hanya mendapatkan nilai rata - rata kelas secara klasikal yaitu 6.5 sementara ketuntasan belajar yang diharapkan mencapai nilai 7.0.

Hal ini disebabkan karena ketidakmampuan siswa dalam menguasai kosakata dalam mengubah kata kerja kedua dan ketiga (irregular verbs), di samping pula metode yang digunakan guru dalam pembelajaran Bahasa Inggris kurang kreatif dan inovatif serta ketidakmampuan guru mengelola pembelajaran di kelas dengan bantuan media yang dapat mempermudah siswa lebih cepat memahami materi Bahasa Inggris. Guru hanya menjelaskan secara gramatika kemudian memberikan tugas dan mengumpul hasil kerja siswa, sehingga kurang optimalnya partisipasi siswa dalam kelas, siswa merasa bosan, motivasi dan gairah belajar kurang dan merasa tertekan apalagi bila jam pelajaran Bahasa Inggris di ajarkan pada jam terakhir pelajaran.

Dengan adanya kondisi diatas maka guru seyogyanya mencari solusi dalam mengatasi pembelajaran yang monoton dan memberikan pemahaman yang lebih efektif kepada siswa sehingga menjadikan pembelajaran Bahasa Inggris yang menyenangkan. Ketidakmampuan siswa dalam menguasai kosa kata pada kata kerja tidak beraturan bisa teratasi dan membantu siswa dalam mengerjakan soal dalam bentuk simple past tense.

Berdasarkan realita diatas maka penulis perlu merevisi pembelajaran bahasa Inggris di kelas X PS 2 agar mendorong siswa lebih aktif dan interaktif dan tertarik tanpa ada rasa bosan dan takut untuk belajar bahasa Inggris terutama pada penguasaan kosa kata (irregular verbs) kata kerja tidak beraturan. Salah satu cara yaitu dengan menggunakan metode Interaktif dalam Permainan kartu Jack and Jacky untuk meningkatkan penguasaan kosa kata pada kata kerja tidak 
beraturan (irregular verbs) pada siswa kelas X PS 2 semester ganjil Tahun 2017/2018 di SMK Negeri 7 Makassar.

\section{Metode Pembelajaran Interaktif}

Metode mengajar sangat mempengaruhi belajar, metode mengajar yang kurang tepat juga akan mempengaruhi belajar siswa. Metode mengajar yang kurang tepat itu dapat terjadi misalnya karena guru kurang persiapan dan kurang menguasai bahan pelajaran sehingga guru tersebut menyajikannya tidak jelas atau sikap guru terhadap siswa dan atau mata pelajaran itu sendiri tidak baik, sehingga siswa kurang senang terhadap pelajaran atau gurunya. Akibatnya siswa malas untuk belajar.

Dalam persoalan metode ini, kita tidak dapat mengatakan mana yang paling baik, secara umum bisa dikatakan bahwa nampaknya semua metode ada baiknya, dan yang paling penting adalah kapan kita harus menggunakan metode yang satu dan dengan yang lain. Hal ini sudah barang tentu tergantung pada tujuan apa yang akan dicapai oleh pengajaran.

Metode bisa dikatakan baik itu semua sangat erat hubungannya dengan kemampuan guru untuk mengorganisir, memilih dan menggiatkan seluruh program kegiatan belajar mengajar. Kemampuan mencari dan menggunakan metode dalam kegiatan belajar mengajar adalah pekerjaan guru sehari-hari. Ini membutuhkan ketekunan dan latihan yang terus menerus. Apakah siswa akan terangsang/tertarik dan ikut serta aktif dalam kegiatan belajar, sangat tergantung pada metode yang dipakai. Aktifnya siswa dalam kegiatan belajar berarti melekatnya hasil belajar itu dalam ingatan.

Berbagai macam metode dalam pembelajaran salah satu yang di ambil adalah Metode interaktif. Ref. [5] menyatakan bahwa pada proses pembelajaran metode interaktif menekankan pada kegiatan diskusi, ditunjukkan dengan adanya kegiatan interaksi antar guru dengan siswa, siswa dengan siswa dengan bahan yang di pelajari Seperti kita ketahui bahwa setiap siswa memiliki pengetahuan dan kemampuan yang berbeda, seringkali siswa yang memiliki kemampuan yang rendah tak bisa turut berpartisipasi dalam proses pembelajaran, sehingga siswa yang memiliki kemampuan terbatas tidak dapat meningkatkan prestasi belajarnya.

Metode interaktif yang mudah digunakan untuk mengajarkan bahasa, yaitu melalui permainan. Ref. [5] menyatakan bahwa ada beberapa kelebihan dari permainan bahasa sebagai media pembelajaran. Kelebihan itu antara lain:

a. Permainan bahasa merupakan media pembelajaran bahasa yang dapat dipakai untuk meningkatkan kadar keaktifan pembelajar dalam proses belajar mengajar.

b. Permainan bahasa dapat dipakai untuk membangkitkan kembali kegairahan pembelajar dalam belajar yang sudah mulai lesu.

c. Sifat kompetitif yang ada dalam permainan dapat mendorong pembelajar untuk berlomba-lomba maju.

d. Selain untuk menimbulkan kegairahan dan melatih keterampilan berbahasa tertentu, permainan bahasa memupuk berbagai sikap yang positif seperti solidaritas, kreatifitas, dan rasa percaya diri.

e. Materi yang dikomunikasikan lewat permainan bahasa biasanya mengesankan sehingga sulit dilupakan.

\section{Permainan Kartu Jack dan Jacky}

Dalam penelitian ini jenis permainan yang akan digunakan adalah permainan kartu Jack and Jacky.

Permainan kartu Jack dan Jacky adalah sejenis kartu berwarna yang berbentuk persegi panjang ukuran 8 x 6 terdiri 64 Kartu tersebut berisi tentang Kosa kata Bahasa Inggris baik itu berupa Verb (kata kerja) Irregular verbs dari bentuk Verb (kata kerja I sampai ke III. Diantara kartu tersebut terdapat dua kartu yang bertuliskan tulisan King dan Queen sebagai tanda langkah awal kartu 
tersebut diturunkan untuk memulai permainan.Kartu Jack and Jacky.

Cara memainkannya:

1. Siswa di bagi dalam beberapa kelompok sebaiknya setiap kelompok terdiri dari 4 orang.

2. Sebelum bermain sebaiknya setiap siswa mempelajari semua kosakata yang ada dalam kartu selama 5 menit atau 10 menit sebelum kartu yang lainnya dibaca pada daftar koskatanya yang ada pada salah satu kartu.

3. Selanjutnya kartu di kocok dan di bagi sama banyak.

4. Pertama kali siswa menurunkan kartu King (terdapat tulisan di dalam kartu) ada dua lembar, kedua kartu tersebut harus di turunkan bersamaan dan letaknya berdekatan

5. Sesudah kartu King diturunkan disusul oleh kartu Queen, Jadi diantara pemain (siswa) yang memiliki kartu Queen, menurunkan kartu Queen-nya dengan segera, kartu Queen ini ada juga dua lembar. Kedua kartu ini harus diturunkan bersamaan dan letaknya berdekatan.

6. Pada Kartu yang diberi tanda A terdapat kata DO. Kata kerja bentuk kedua dan ketiga dari DO ialah DID dan DONE. Jadi Kalau siswa memiliki kartu DID dan DONE, siswa menurunkan kartu itu segera. Sedangkan kartu yang diberi tanda B, C, dan D masing terdapat kata SLEEP, TAKE, dan SEE. Kata kerja bentuk kedua dan ketiganya SLEPTSLEPT, TOOK-TAKEN, SAW-SEEN. Jadi, bila siswa yang memiliki kartu tersebut siswa menurunkan kartu itu segera. Siswa yang cepat menyelesaikan kartu yang dimiliki dengan urutan kata kerja yang benar dan sesuai dialah yang menjadi pemenang pertama dan mendapatkan nilai 10 , yang nomor dua menyelesaikan kartunya mendapatkan nilai 8 , yang nomor tiga habis kartunya mendapatkan nilai 6 , sedangkan yang nomor empat habis kartunya mendapat nilai 4.

\section{METODE PENELITIAN}

Penelitian ini menggunakan penelitian tindakan kelas (action research) yang dilakukan dengan tujuan memperbaiki mutu pembelajaran di kelas supaya lebih baik. Penelitian Tindakan Kelas merupakan suatu pencermatan terhadap kegiatan belajar mengajar berupa sebuah tindakan yang sengaja di munculkan dan terjadi dalam sebuah kelas secara bersamaan [6]. Pada penelitian ini digunakan penelitian tindakan kelas model Kurt Lewin yang menyatakan bahwa PTK terdiri atas beberapa siklus, setiap siklus terdiri atas empat langkah, yaitu: (1) perencanaan, (2) aksi atau tindakan, (3) observasi, dan (4) refleksi.

Objek tindakan dalam penelitian ini adalah penerapan metode interaktif dalam permainan Kartu "Jack dan Jacky" untuk meningkatkan kemampuan kosakata pada kata kerja bahasa Inggris (Irregular verbs) pada kompetensi simple past tense siswa kelas X PS2 (Pekerja Sosial) semester ganjil tahun 2017/2018 di SMK Neg.7 Makassar.

Waktu pelaksanaan penelitian di lakukan selama 2 bulan mulai bulan Oktober 2017 pada minggu ketiga dan keempat, kemudian bulan Nopember 2017 pada minggu pertama dan minggu kedua. Adapun lokasi yang dijadikan subyek penelitian ini adalah siswa kelas X PS 2 (Pekerja Sosial) yang berjumlah 24 orang siswa terdiri dari 1 laki laki dan 23 perempuan pada semester ganjil tahun 2017/2018 di SMK Negeri 7 Makassar J1. Ince Nurdin No.35 Makassar. Kelas ini dipilih berdasarkan survei dan kondisi awal dari hasil belajar siswa yang rendah, motivasi siswa dalam mata pelajaran Bahasa Inggris ini kurang baik, serta keaktifan siswa yang pasif dalam menerima pelajaran.

Metode pengumpulan data yang digunakan dalam penelitian ini adalah dengan menggunakan tes, non tes, observasi, dokumentasi, jurnal pembelajaran siswa dan angket.

HASIL PENELITIAN 


\section{Siklus I}

Pada pertemuan tindakan sikus I, peneliti menerapkan Metode Interaktif dalam permainan Kartu "Jack dan Jacky "dalam pembelajaran bahasa Inggris. Hasil nilai siswa pada siklus I dari 24 siswa yang ikut tes siswa yang berada pada interval skor 70-84 berjumlah 21 orang atau $87.5 \%$ dengan kategori baik, sedangkan pada kategori cukup dengan interval skor 60-69 masih ada 3 siswa dengan persentase $12.5 \%$ dan belum mencapai nilai ketuntasan belajar meskipun sudah mengalami peningkatan jika dibandingkan sebelum adanya tindakan, masih adanya siswa yang mendapat nilai 5.0 dengan kategori kurang pada interval 50-59 pada pretes. Perolehan nilai rata-rata kelas pada siklus 1 mencapai peningkatan dari 6.5 menjadi 7.2.

\section{Siklus II}

Pada tahap Pelaksanan siklus II guru menjelaskan permasalahan yang ditemukan pada siklus sebelumnya terkait dengan kosakata pada kata kerja (irregular verbs) untuk menambah penguasaan kosakata tersebut, selain itu lebih memberikan latihan pelafalan dan intonasi pada kata kerja tidak beraturan maupun kata kerja yang tidak beraturan.

Pada siklus II adanya peningkatan ratarata kelas yaitu meningkat menjadi 7.97 , dengan perincian bahwa sudah tidak satupun siswa yang berada di bawah KKM 6.5 dibanding pada siklus I masih ada 3 orang siswa pada interval skor 60-69 dengan kategori cukup. Adapun Interval skor 70-84 pada kategori baik jumlah siswa ada 17 siswa atau $70.83 \%$, Sedangkan siswa yang memperoleh interval skor antara 85-100 ada 7 siswa atau $29.16 \%$ dibanding pada siklus I perolehan nilai kategori baik sekali belum ada. Ini menunjukkan Hasil belajar siswa pada penguasaan kosakata pada kata kerja tidak beraturan (Irregular Verbs) meningkat secara signifikan dan berada pada pencapaian target di atas nilai minimal KKM 7.0.
Rekapitulasi nilai hasil tes siswa kelas X PS 2 semester ganjil Tahun 2017/2018 di SMK Negeri 7 Makassar bisa di lihat tabel dibawah ini

Tabel 1. Rekapitulasi Hasil Tes Pada Pretes, Siklus I dan Siklus II

\begin{tabular}{cccc}
\hline Subyek & PRETE & SIKLU & SIKLU \\
Penelitia & S & S I & S II \\
$n$ & & &
\end{tabular}

\begin{tabular}{llll}
\hline Siswa & 6.5 & 7.2 & 7.97 \\
Kelas X & & & \\
PS2 & & & \\
Semester & & & \\
Ganjil & & & \\
Thn & & & \\
$2017 / 201$ & & & \\
8 & & & \\
& & &
\end{tabular}

Hasil rekapitulasi Penilaian hasil tes belajar dapat di lihat peningkatan dengan menggunakan metode interaktif dalam permaianan kartu Jack dan Jacky secara grafik seperti di bawah ini:

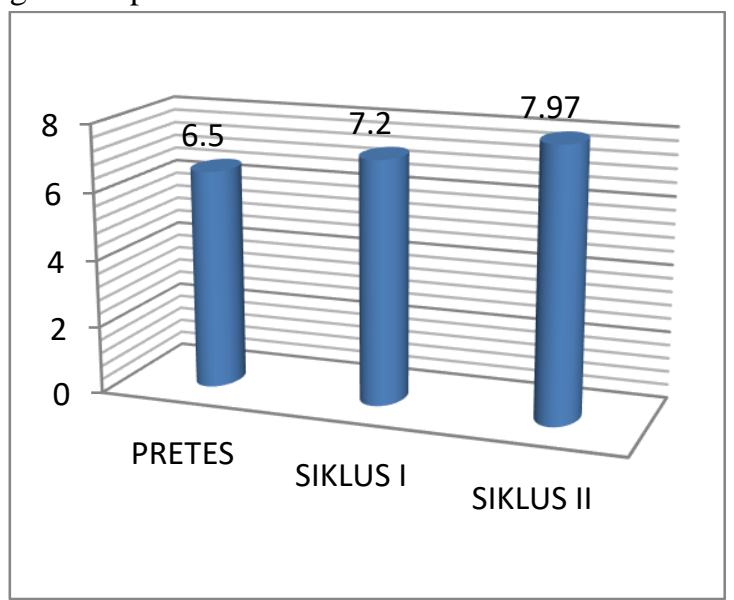

Grafik 1. Rekapitulasi hasil belajar Pretes, siklus 1 dan siklus II

Adapun rekapitulasi untuk penilaian non tes pada siklus I dan siklus II dilakukan dengan observasi/pengamatan untuk mengetahui sejauh mana perubahan perilaku dan sikap siswa dalam pembelajaran dengan menggunakan metode Interaktif dalam permainan kartu Jack dan Jacky dapat dilihat secara grafik di bawah ini: 


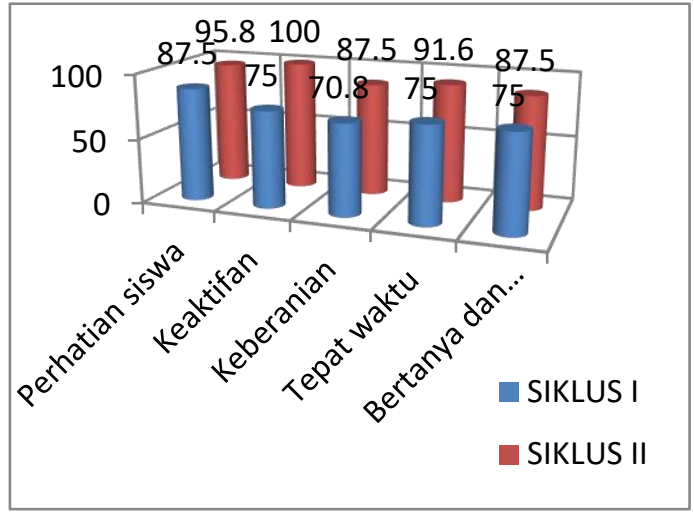

Grafik 2. Rekapitulasi hasil Pengamatan pada siklus I dan siklus II

\section{PEMBAHASAN}

Berdasarkan tindakan pada siklus I dan siklus II, setiap tindakan dimulai dengan adanya Perencanaan mengajar. Perencanaan ini merupakan kegiatan memperkirakan dan memprediksikan mengenai tindakan apa yang akan dilakukan pada waktu tindakan siklus I dan siklus II dengan mengkoordinasikan unsur-unsur pengajaran yaitu tujuan, bahan ajar, metode, dan alat, serta evaluasi/penilaian.

Tujuan berfungsi untuk menentukan arah kegiatan pengajaran dan menentukan kemana siswa akan dibawa. Bahan ajar berfungsi untuk memberi isi atau makna terhadap tujuan. Metode dan alat berfungsi untuk menentukan cara bagaimana mencapai tujuan. Sedangkan penilaian berfungsi untuk mengukur seberapa jauh tujuan itu telah tercapai dan tindakan apa yang harus dilakukan bila tujuan belum tercapai.

Perencaan pembelajaran bahasa Inggris dengan menggunakan permainan kartu "Jack dan Jacky" dibuat berdasarkan hasil pengamatan/observasi pada kegiatan pretes sebelum dilaksanakan tindakan. Adapun rencana yang dilakukan meliputi:

1. Menentukan tujuan pembelajaran.

2. Membuat rencana pelaksanaan pembelajaran (RPP).

3. Mempersiapkan media apa yang hendak digunakan dalam pembelajaran.

4. Mempersiapkan instrument penelitian, dan lain-lain.
Pada pelaksanaan tindakan siklus I dan siklus II dilakukan dengan langkah langkah berdasarkan skenario pembelajaran dengan menerapkan metode interaktif melalui permainan kartu Jack dan Jacky dalam Kemampuan Kosa kata Kelas X PS 2 pada Kata kerja tidak beraturan (irregular verbs) dengan pokok bahasan Simple Past Tense.

Berdasarkan hasil dari pre tes yang telah dilakukan sebelum menerapkan metode interaktif melalui permainan kartu Jack dan Jacky diketahui bahwa nilai rata- rata kelas berada pada 6.5 , nilai ini masih di bawah KKM pada pembelajaran Bahasa Inggris. Sedangkan pada siklus I dan siklus II sudah ada peningkatan nilai rata- rata kelas secara klasikal dan signifikan dari 7.2 menjadi 7.97, dengan penerapan Metode Interaktif melalui permainan kartu "Jack dan Jacky" yang dapat meningkatkan hasil belajar kemampuan kosakata pada kata Kerja tidak beraturan (irregular verbs) pada pokok bahasan simple past tense kelas X PS 2 semester Ganjil Tahun 2017/2018 Di SMK Neg. 7 Makassar.

Dari hasil penilaian selama proses pembelajaran berdasarkan tes maupun non tes dalam pembelajaran Bahasa Inggris dengan menggunakan permainan kartu Jack dan Jacky mengalami peningkatan yang signifikan, hal tersebut dapat dilihat dari sikap, minat, dan perhatian siswa selama proses belajar mengajar. Siswa merasa senang, bersemangat terhadap pembelajaran bahasa Inggris, suasana kelas menjadi hidup; keberanian dalam mengemukakan pendapat, perasaan malu malu dan takut bertanya dan menjawab sudah hilang; siswa dapat menambahkan kosakata yang baru khususnya kata kerja tidak beraturan pada pokok bahasan simple past tense pada kata kerja yang tidak beraturan (irregular verbs) pada siswa kelas X PS 2 SMK Negeri 7 Makassar.

\section{KESIMPULAN}

Berdasarkan hasil penelitian tindakan kelas yang telah dilaksanakan dalam dua siklus pada kelas X PS 2 yang memiliki masalah pembelajaran Bahasa Inggris dalam Penguasaan kosakata siswa maka dapat disimpulkan 1. Adanya peningkatan hasil 
belajar dengan melihat pada pencapaian nilai rata-rata kelas yaitu 6.5 pada prestes menjadi 7.2 pada siklus I yang berarti mengalami peningkatan sebesar $0.7 \%$ sedangkan dari siklus I rata-rata kelas mencapai 7.2 menjadi 7.97 pada siklus II terjadi perubahan perilaku siswa pada pembelajaran Bahasa Inggris setelah menggunakan metode interaktif melalui permainan kartu Jack dan Jacky," Perubahan perilaku itu adalah perhatian siswa keaktifan dalam pembelajaran, keberanian dalam bertanya dan menjawab serta menyelesaikan pekerjaan tepat waktu juga menunjukkan perubahan yang positif

\section{DAFTAR PUSTAKA}

[1] Yusran Pora. 2001. Enrich Our Vocabulary Through Reading and Idioms. Yogyakarta: Pustaka pelajar.

[2] Purwo. 1993. Pembelajaran Bahasa, Jakarta IKIP Yogjakarta: Remaja Rosdakarya.

[3] Murti, Anggi Ellisa. 2011. Pengaruh Penggunaan Media Permainan Bahasa Scramble Terhadap Penguasaan Kosakata Bahasa Indonesia Siswa Kelas II SD Bangunharjo Tahun Ajaran 2010/2011. Skripsi. Yogyakarta: FIP UNY.

[4] Thornbury, S. 2002. How to teach vocabulary. Essex: Pearson Education Limited.

[5] Ali, Muhammad. 2004. Guru dalam Proses Belajar Mengajar. Bandung: Sinar Baru Algesindo.

[6] Soepano. 1980. Media pengajaran Bahasa. Yogyakarta: Ikip Yogyakarta.

[7] Arikunto Suharsimi. 2002. Prosedur Penelitian. Jakarta: Rineka Cipta. 